University of Nebraska - Lincoln

DigitalCommons@University of Nebraska - Lincoln

Publications from USDA-ARS / UNL Faculty

U.S. Department of Agriculture: Agricultural

Research Service, Lincoln, Nebraska

2008

Comparison of Corn and Switchgrass on Marginal Soils for

Bioenergy

Gary E. Varvel

University of Nebraska-Lincoln, gevarvel@windstream.net

Kenneth P. Vogel

University of Nebraska-Lincoln, kvogel1@unl.edu

Robert B. Mitchell

University of Nebraska-Lincoln, rob.mitchell@ars.usda.gov

R. F. Follett

USDA-ARS, ronald.follett@ars.usda.gov

J. M. Kimble

USDA-NRCS

Follow this and additional works at: https://digitalcommons.unl.edu/usdaarsfacpub

Part of the Agricultural Science Commons

Varvel, Gary E.; Vogel, Kenneth P.; Mitchell, Robert B.; Follett, R. F.; and Kimble, J. M., "Comparison of Corn and Switchgrass on Marginal Soils for Bioenergy" (2008). Publications from USDA-ARS / UNL Faculty.

242.

https://digitalcommons.unl.edu/usdaarsfacpub/242

This Article is brought to you for free and open access by the U.S. Department of Agriculture: Agricultural Research Service, Lincoln, Nebraska at DigitalCommons@University of Nebraska - Lincoln. It has been accepted for inclusion in Publications from USDA-ARS / UNL Faculty by an authorized administrator of DigitalCommons@University of Nebraska - Lincoln. 


\title{
Comparison of corn and switchgrass on marginal soils for bioenergy
}

\author{
G.E. Varvel ${ }^{a, *}$, K.P. Vogel ${ }^{a}$, R.B. Mitchell ${ }^{a}$, R.F. Follett ${ }^{b}$, J.M. Kimble \\ aUSDA-ARS, 344 Keim Hall, University of Nebraska-Lincoln, P.O. Box 830937, Lincoln, NE 68583-0937, USA \\ bUSDA-ARS, Room S-100, 2150 Centre Avenue Building D, Ft. Collins, CO 80526-8119, USA \\ 'USDA-NRCS, National Soil Survey Center, 100 Centennial Mall North, Lincoin, NE 68508-3866, USA
}

\section{A R T I C L E I N F O}

\section{Article history:}

Received 7 June 2007

Received in revised form

29 June 2007

Accepted 3 July 2007

Available online 16 August 2007

Keywords:

Residue removal

Ethanol

No-till corn

Switchgrass

Bioenergy

Biomass

\begin{abstract}
A B S T R A C T
Crop residues such as corn (Zea mays L.) stover are viewed as an abundant and inexpensive source of biomass that can be removed from fields to produce bioenergy. Assumptions include that with minimum or no-tillage farming methods, there will be no deleterious production or environmental effects. A long-term field study was established in eastern Nebraska, USA, to compare the switchgrass managed as a biomass energy crop versus no-till corn on a non-irrigated site, marginal for row-crop production, in the western Corn Belt. Our objective in this paper is to report on corn stover removal effects on corn grain yields and potential ethanol production in both cropping systems. Com, under no-till management, and switchgrass were grown at three $\mathrm{N}$ fertilizer levels. In the first 5 years (2001-2005), removal of half the available stover significantly reduced corn yields. During that same time period, the potential ethanol yield for switchgrass was equal to or greater than the potential total ethanol yield of corn grain and harvested stover fertilized at the same optimum $\mathrm{N}$ rate. The effect of crop residue removal on crop productivity needs to be investigated in other agro-ecosystems and the potential use of dedicated perennial biomass energy crops should remain a viable renewable energy option on non-irrigated marginal croplands.
\end{abstract}

Published by Elsevier Ltd.

\section{Introduction}

As the technology for converting plant cell wall cellulose and hemicellulose to ethanol becomes more economical, renewable energy from plant biomass has the potential to replace fossil fuels as a source of liquid fuels [1,2]. From 1978 to 2002 , a research focus of the US Department of Energy (DOE) was the development of herbaceous and woody plants as biomass energy crops $[3,4]$. The DOE-funded research on perennial energy crops such as switchgrass (Panicum virgatum L.) was largely discontinued in 2002 and the focus shifted to the use of crop residues for biomass energy. Crop residues such as corn (Zea mays L.) stover (residue left after grain is harvested) are viewed as an abundant, inexpensive source of biomass that can be removed from fields without deleterious production or environmental effects if proper management is used $[1,2]$. Such management includes using minimum- or notillage farming methods and leaving sufficient residue on the land (about 30\%) to prevent soil erosion [5].

Crop residues are the source for soil organic carbon (SOC), which is essential for maintaining soil productivity $[6,7]$. The importance of maintaining or improving SOC via minimum and no-till farming systems is viewed as essential in maintaining the productivity of agricultural lands $[6,7]$. In

*Corresponding author. Tel.: +14024725169; fax: +14024720516.

E-mail address: gvarvel1@unl.edu (G.E. Varvel). 0961-9534/\$- see front matter Published by Elsevier Ltd. doi:10.1016/j.biombioe.2007.07.003 
addition to serving as a source for SOC, crop residues reduce soil erosion, enhance water infiltration, and reduce evaporation.

In 1998, we established a long-term carbon (C) sequestration field study in eastern Nebraska, USA, to compare the Csequestration of switchgrass managed as a biomass energy crop versus no-till corn. In 2000, after we became aware of the biomass energy emphasis shift to crop residues, a residue harvest component was added to the experiment and this paper reports on residue removal effects on corn grain yields in a non-irrigated semi-arid environment. At the same time, potential ethanol production in the no-till corn production system (ethanol from grain and harvested residue) will also be compared with potential ethanol production from switchgrass in this same environment.

\section{Materials and methods}

This on-going, long-term field study is located on the University of Nebraska Agricultural Research and Development Center, Ithaca, Nebraska, USA (latitude $41.15^{\circ}$, longitude $-96.40^{\circ}$ ) on an Aksarben silty clay loam (fine, smectitic, mesic Typic Argiudoll). The experimental design is a split-split plot, randomized complete block. Main treatments are two cultivars of switchgrass, Trailblazer and Cave-in-Rock, and no-till corn. There are three replicates of switchgrass and corn main plots. Switchgrass is managed as a biomass crop and corn is managed as a no-tillage grain crop. Subplot treatments are $\mathrm{N}$ fertilizer levels and sub-sub plots are harvest treatments. Nitrogen fertilizer rates used in the period 2000-2005 were $\mathrm{N} 1=0, \mathrm{~N} 2=60, \mathrm{~N} 3=120$, and $\mathrm{N} 4=180 \mathrm{~kg} \mathrm{Nha}^{-1}$ as $\mathrm{NH}_{4} \mathrm{NO}_{3}$, broadcast on the plots at the start of the growing season. N1, N2, and N3 rates are used on switchgrass plots; N2, N3, and N4 rates are used on corn. Main plots are split into three subplots that are $30 \mathrm{~m}$ long $\times 18.3 \mathrm{~m}$ wide. Subplots are separated by a $15 \mathrm{~m}$ wide alley so that field-scale equipment can be used for harvesting plots. Subplots were split lengthways to produce paired sub-subplots that are $30 \mathrm{~m}$ long and $9.15 \mathrm{~m}$ wide. Switchgrass plots were seeded in the spring of 1998 into a field that was in soybeans (Glycine max (L.) Merr.) the previous year. Soybeans were planted in the grain crop plots in 1998 and beginning in 1999, these plots have been planted to corn each year. The corn commercial hybrid DK 589 RR (trade names and company names are included for the benefit of the reader and do not imply any endorsement or preferential treatment of the product by the authors, USDAAgricultural Research Service, or the Agricultural Research Division of the University of Nebraska), has been used each year. Corn row width is $0.76 \mathrm{~m}$. Herbicides have been used for weed control as needed in both corn and switchgrass plots.

Corn fertility subplots plots were split into sub-subplots in 2000 and one of the sub-subplots within a subplot was permanently assigned for stover harvest. Corn grain yields have been determined with a plot combine equipped with a weighing unit. Yields are harvested from the center three rows of each plot by a plot combine and are reported on a dryweight basis. The remaining area of the corn plots is harvested with a commercial combine. Total biomass of corn is determined for each sub-subplot by harvesting a $4.4 \mathrm{~m}$ long section of a plot row and weighing the total biomass before grain harvest. Stover was harvested on the designated subsubplots after grain harvest with flail forage harvesters that also are used to harvest switchgrass plots. Two harvest treatments are being used on switchgrass: one in mid-August and one after a killing frost using the same sub-subplot design as for corn. In 2000 , a $1.83-\mathrm{m}$ wide swath was harvested from the full $30-\mathrm{m}$ length of sub-subplots using a field flail harvester to determine harvested stover or switch. grass biomass yield. Since 2001, Carter plot harvesters with large weigh boxes and load cells have been used to obtain plot yield estimates for both corn stover and switchgrass biomass. Two rows ( $1.52 \mathrm{~m}$ wide) were harvested the length of the subsubplots to obtain plot yields for corn stover. Switchgrass plot yields were obtained by harvesting a $1.2 \mathrm{~m}$ (2000 and 2001) or $0.9 \mathrm{~m}$. (2002 through 2004) wide swath the length of the plots. After stover harvests were completed with the plot harvester, the stover on remaining rows of the harvested plots was harvested with a field flail harvester. A similar procedure was used on the switchgrass plots. The harvesting height for both the plot flail harvester and the field flail harvester was $10 \mathrm{~cm}$ for corn stover and switchgrass. Stover residue left on the field was determined by difference. Corn stover and switchgrass biomass subsamples were collected at the time of harvest, weighed in the field, and then dried in a forced-air oven at $50^{\circ} \mathrm{C}$ to a constant weight. Plot yields were adjusted to a dry-weight basis.

Potential ethanol production in each of the cropping systems was calculated using published rates for conversion of both grain and stover to ethanol. The rate for converting corn grain to ethanol was $0.4321 \mathrm{~kg}^{-1}$ [8] and that for converting switchgrass biomass and corn stover to ethanol was $0.3291 \mathrm{~kg}^{-1}[1,8,9]$.

Data from the study were analyzed both within and across years. All statistical analyses were performed using PC Version 9.1 of the Statistical Analyses System for Windows [10].

\section{Results and discussion}

Analyses of the corn grain, stover, and total above-ground biomass yield data across years indicated no significant year by $\mathrm{N}$ fertilizer level or year by harvest amount (stover) interactions. Therefore, since yield responses were consistent across all 5 years of the study, data will only be presented for the main effects of $\mathrm{N}$ fertilizer and stover harvest.

Nitrogen fertilizer significantly affected corn grain, stover, and total above-ground biomass yields (probability level, $p=0.05$ ) over the duration of the study (2001-2005), as shown in Fig. 1. This is not new or unique information; similar results have been reported from a continuous corn cropping system in long-term rotation study in the same geographic area [11].

As mentioned earlier in the introduction, the focus of DOEfunded research in the US has shifted to the use of crop residues for biomass energy. This component of the study, residue harvest, directly addresses some of the concerns, especially its effect on future crop yields. The amount of stover removed has varied with years even though the same equipment has been used. Mean stover removal was $42 \%$, 


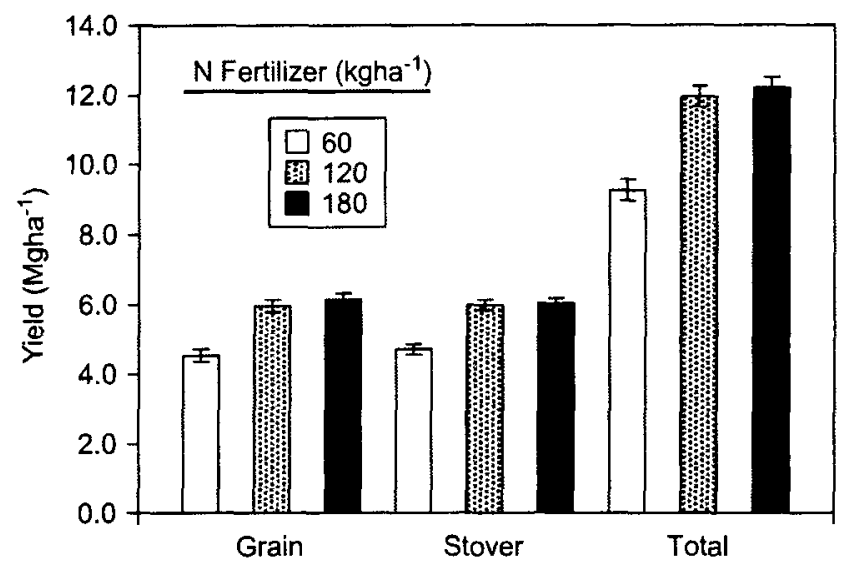

Fig. 1 - Corn grain, stover, and total above-ground biomass yields in a non-irrigated no-till continuous corn cropping system as affected by $N$ fertilizer levels averaged over years (2001-2005) at Ithaca, Nebraska, USA. Standard error (SE) bars are presented for corn grain, stover, and total above-ground biomass yields.

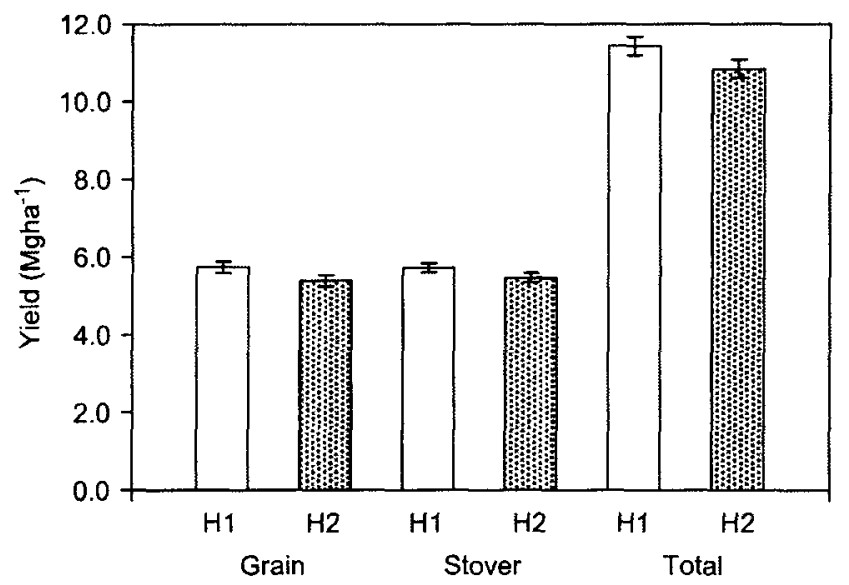

Fig. 2 - Corn grain, stover, and total above-ground biomass yields in a non-irrigated no-till continuous corn cropping system as affected by stover removal levels averaged over years (2001-2005) at Ithaca, Nebraska, USA. Stover removal levels were none (H1) and 51\% (H2) (average removal from 2000 to 2004). Standard error (SE) bars are presented for corn grain, stover, and total above-ground biomass yields.

$62 \%, 38 \%, 45 \%$, and $68 \%$ in $2000,2001,2002,2003$, and 2004 , respectively. Averaged over years, the amount of stover harvested was $51 \%$. These levels of residue removal $(\mathrm{H} 2)$ versus no residue removal (H1) significantly reduced corn grain, stover, and total above-ground biomass yield (probability level, $p=0.10$ ) over the duration of the study (2001-2005), as shown in Fig. 2. These results indicate that in the agro-ecosystem of the western Corn Belt, USA, corn stover removal for biomass energy from non-irrigated fields may not be sustainable under no-till farming at suggested removal rates used in biomass energy analyses. This research is supported by earlier reports on the effect of stover removal on corn yields in the Midwest [12-14].

The loss of corn grain yields in this study was due to the reduction in the beneficial effects of previous years' crop residue on plant productivity. The effect of com stover removal on soil fertility has been shown to have a residual effect 10 years after removal ceased [14].
Since switchgrass was grown in the same trial, the potential ethanol productivity of switchgrass and corn could be directly compared. Over the period, 2000-2004, the potential ethanol yield for switchgrass fertilized at the same rate as corn was equal to or greater than the potential total ethanol yield of corn grain and harvested stover (Fig. 3). This study is located on one of the less fertile fields in the University of Nebraska's Agricultural Research and Development Center, Ithaca, Nebraska, and was chosen because it represents the type of marginal land currently in the Conservation Reserve Program (CRP). Land in the CRP is a potential land base for perennial biomass energy crops [9]. These results support previous indirect comparisons [9] and demonstrate that perennial herbaceous energy crops can produce as much ethanol per hectare on marginal, surplus cropland as grain crops.

The effect of crop residue removal for biomass energy should be thoroughly investigated in field trials in each major 


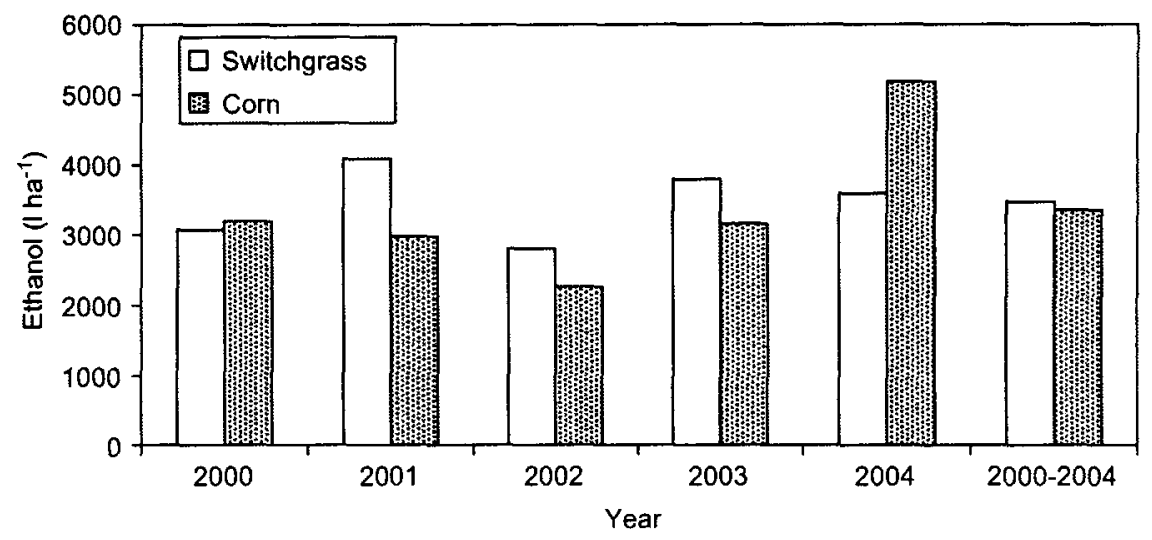

Fig. 3 - Predicted ethanol yields from switchgrass biomass and corn (grain+amount from harvested stover) for each year, 2000-2004, and the average (2000-2004) at the $120 \mathrm{~kg} \mathrm{~N} \mathrm{ha}^{-1}$ fertilizer rate at Ithaca Nebraska, USA. Switchgrass ethanol yields are averaged over two cultivars and two harvest treatments.

agro-ecosystem before biomass energy conversion facilities are built and widespread crop residue removal is initiated. The potential use of dedicated perennial biomass energy crops should also remain a viable renewable energy option on non-irrigated marginal croplands.

REFERENCES

[1] Kim S, Dale BE. Global potential bioethanol production from wasted crops and crop residues. Biomass Bioenergy 2004;6:361-75.

[2] Gallager P, Dikeman M, Fritz J, Wailes E, Gauther W, Shapouri H. Biomass from crop residues: cost and supply estimates. Agricultural Economic Report 819, USDA Office of the Chief Economist, Office of Energy Policy and New Uses. Room 361, Reporters Building, 300 7th Street SW, Washington, DC: 2003.

[3] McLaughlin S, Bouton J, Bransby D, Conger B, Ocumpaugh W, Parrish $\mathrm{D}$, et al. Developing switchgrass as a bioenergy crop. In: Janick J, editor. Perspectives on new crops and new uses. Alexandria, VA: ASHS Press; 1999. p. 282-99.

[4] McLaughlin SB, de la Torre Ugarte DG, Garten Jr. CT, Lynd LR, Sanderson MA, Tolbert VR, et al. High-value renewable energy from prairie grasses. Environ Sci Technol 2002;36:2122-9.
[5] Wilhelm WW, Johnson JMF, Hatfield JL, Voorhees WB, Linden DR. Crop and soil productivity response to corn residue removal: a literature review. Agron J 2004;96:1-17.

[6] Jarecki MK, Lal R. Crop management for soil carbon sequestration. Crit Rev Plant Sci 2003;22:471-502.

[7] Lal R. Soil carbon sequestration impacts on global climate change and food security. Science 2004;304:1623-7.

[8] Turhollow $A F$, Johnson JW, Cushman JH. Linking energy crop production to conversion: the case of herbaceous lignocellulosic crops to ethanol. RERIC Int Energy J 1988;10:41-9.

[9] Vogel KP. Energy production from forages (or American agriculture-back to the future). J Soil Water Conserv 1996;51:137-9.

[10] SAS Institute. SAS/STAT user's guide. Release 9.1 ed. Cary, NC: SAS Institute, Inc.; 2003.

[11] Varvel GE, Wilhelm WW. Soybean nitrogen contribution to corn and sorghum in two-year cropping systems in the Westem Corn Belt. Agron J 2003;95:1220-5.

[12] Linden DR, Clapp CE, Dowdy RH. Long-term corn grain and stover yields as a function of tillage and residue removal in east central Minnesota. Soil Tillage Res 2000;56:167-74.

[13] Power JF, Koemer PT, Doran JW, Wilhelm WW. Residual effects of crop residues on grain production and selected soil properties. Soil Sci Soc Am J 1998;62:1393-7.

[14] Wilhelm WW, Doran JW, Power JF. Corn and soybean yield response to crop residue management under no-tillage production systems. Agron J 1986;78:184-9. 